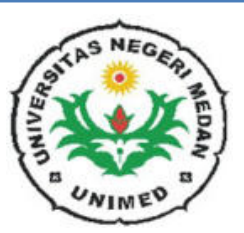

\author{
JURNAL BIOSAINS \\ (Journal of Biosciences) \\ http://jurnal.unimed.ac.id/2012/index.php/biosains \\ email : jbiosains@unimed.ac.id
}

\title{
PEMBUATAN BIOPESTISIDA DARI EKSTRAK DAUN SIRSAK (Annona muricata) UNTUK PENGENDALIAN HAMA ULAT API (Setothosea asigna V.Eecke) PADA TANAMAN KELAPA SAWIT (Elaeis guineensis Jacq)
}

\author{
Gimelliya Saragih, Benny Rio Fernandez, Yunianto, Harmileni \\ Politeknik Teknologi Kimia Industri Medan \\ E-mail korespondensi: harmileni16@gmail.com
}

Diterima: 5 Februari 2019; Direvisi: 25 Februari 2019; Disetujui: 6 Maret 2019

\begin{abstract}
ABSTRAK
Ulat api (Setothosea asigna V.Eecke) merupakan hama pemakan daun yang terpenting di perkebunan kelapa sawit terutama di Sumatera Utara. Ulat ini dikenal sebagai ulat yang rakus yang sering menimbulkan kerugian di perkebunan kelapa sawit pada tanaman muda maupun tanaman tua. Pada perkebunan kelapa sawit, ulat pemakan daun kelapa sawit umumnya diatasi dengan menggunakan insektisida kimia sintetik yang mampu menurunkan populasi hama dengan cepat, sehingga dapat dihindari terjadinya kerusakan daun lebih lanjut. Walaupun demikian, penggunaan insektisida kimia sintetik secara kurang bijaksana telah terbukti dapat menimbulkan berbagai dampak negatif terhadap lingkungan. Tujuan penelitian ini adalah pembuatan biopestisida dari daun sirsak untuk mengendalikan hama ulat api (Setothosea asigna V.Eecke). Daun sirsak diekstrak dengan pelarut etanol 96\%. Ekstrak pekat yang diperoleh diencerkan dengan akuades menjadi beberapa variasi konsentrasi yaitu 10\%, 20\%, 30\%, 40\% dan 50\%. Metode uji insektisida yang digunakan adalah metode racun kontak, yaitu menyemprotkan secara langsung ekstrak daun sirsak ke tubuh ulat api dan dilanjutkan dengan pengamatan. Hasil uji insektisida menunjukkan ekstrak daun sirsak 30\% sudah efektif dalam mengendalikan hama ulat api. Dari hasil tersebut disimpulkan bahwa daun sirsak dapat dimanfaatkan sebagai biopestisida dalam mengendalikan hama ulat api dengan mekanisme racun kontak.
\end{abstract}

Kata Kunci : Setothosea asigna V.Eecke, biopestisida, daun sirsak, racun kontak

\section{BIOPESTICIDE FROM SOURSOP (Annona muricata) LEAVES EXTRACT FOR CONTROL OF SETOTHOSEA ASIGNA V.EECKE ON PALM OIL PLANT (Elaeis guineensis Jacq)}

\begin{abstract}
Setothosea asigna V.Eecke was the most important caterpillar in palm oil plantations in North Sumatera. These caterpillars are known as greedy pests which often causes losses on palm oil plantations. In palm oil plantations, palm leaf-eating caterpillars generally removed by using synthetic chemical insecticide which could reduce the pests population rapidly. However, the use of syntetic insecticide will cause the negative effect on the environment. The aim of the study was to produce biopesticide from soursop leaves to control Setothosea asigna V.Eecke, the palm oil pests. Soursop leaves was extracted with ethanol $96 \%$ as solvent. Crude extract was diluted using distilled water into several variation concentration , 10\%, 20\%, $30 \%, 40 \%$ and $50 \%$. The method that used in this study was contact poison method.The insecticide assat showed crude extract $30 \%$ was effective in controlling Setothosea asigna V.Eecke. It concluded that the soursop leaves could utilized as biopesticide in controlling of Setothosea asigna V.Eecke with contact poison mechanism
\end{abstract}

Keywords: Setothosea asigna V.Eecke, biopesticide, soursop leaves, contact poison 


\section{Pendahuluan}

Dalam dua dekade terakhir, kelapa sawit merupakan komoditi andalan negara Indonesia terutama dalam bidang ekspor dan sekaligus sebagai komoditi yang sangat diharapkan dalam peningkatan pendapatan petani perkebunan. Salah satu keunggulan tanaman ini adalah tanaman ini cukup toleran terhadap berbagai kendala dibandingkan dengan tanaman lain. Salah satu gangguan yang dapat menurunkan produktivitas kelapa sawit adalah adanya organisme pengganggu tanaman, dimana salah satunya adalah ulat api (Setothosea asigna V.Eecke) (Sinaga $\mathrm{M}$ dan Oemry S, 2015). Ulat ini merupakan ancaman serius terhadap perkebunan kelapa sawit. Di Indonesia, ulat api ini menyerang daun tua maupun daun muda dan kerusakan yang ditimbulkan lebih dari $70 \%$ pada tahun pertama, dan 90\% pada tahun kedua (Saleh \& Siregar, 2017). Dalam pengendalian organisme tanaman pengganggu, petani umumnya menggunakan pestisida. Pestisida digunakan secara luas dalam banyak sektor pertanian untuk mencegah atau mengurangi kerugian akibat hama tanaman, bahkan dapat meningkatkan hasil pertanian. Pestisida dapat dipertimbangkan sebagai pengendali hama tanaman yang efisien dan ekonomis. Tetapi popularitas pestisida dan penggunaan yang berlebihan berpotensi menimbulkan masalah kesehatan pada manusia terutama petani. Petani dapat terpapar pestisida saat mencampurkan dan mengaplikasikan pestisida di perkebunan. Di negara berkembang seperti Indonesia, petani menghadapi risiko besar terpapar dikarenakan penggunakan bahan kimia berbahaya yang dilarang di negara lain, teknik aplikasi yang tidak tepat, alat semprot yang tidak terawat, dan seringnya penggunaan kembali kontainer pestisida yang telah lama untuk penyimpanan air dan makanan (Damalas \& Eleftherohorinos, 2011). Dampak negatif lain dari penggunaan pestisida adalah terganggunya populasi serangga yang menguntungkan seperti penyerbuk dan musuh alami hama di lahan pertanian. Sebagian besar insektisida sintetis memiliki aktivitas dengan spectrum luas yang dapat membunuh serangga yang menguntungan dan hama sekaligus (Ndakidemi et al., 2016). Menurut US Environmental Protection Agency (USEPA), biopestisida adalah pestisida yang diturunkan dari bahan alam seperti hewan, tanaman, bakteri dan mineral. Pestisida biokimia adalah senyawa kimia yang diekstrak dari sumber bahan alam yang bisa digunakan dalam mengendalikan hama. Salah satu jenis dari biopestisida adalah pestisida nabati (Sharma \& Thakur, 2018). Pestisida nabati relatif tidak berbahaya terhadap organisme non target, termasuk manusia dan juga mudah terurai (biodegradable) dan tidak mencemari lingkungan. Beberapa tanaman dapat digunakan sebagai pestisida nabati (Khater \& Khater, 2009). Salah satu tanaman obat yang sering diteliti adalah tanaman sirsak (Annona muricata). Tanaman ini diketahui memiliki aktivitas anti kanker, anti bakteri, aktivitas sitotoksik, serta memiliki kandungan antioksidan yang tinggi (Pai et al., 2016). Ekstrak daun sirsak juga diketahui memiliki aktivitas larvasida terhadap Plutella xylostella, salah satu hama yang menyerang tanaman kubis (Trindade et al., 2016). Penelitian ekstrak daun sirsak sebagai pestisida nabati masih sangat terbatas. Tujuan penelitian ini adalah mengetahui apakah daun sirsak berpotensi sebagai pestisida nabati terhadap hama ulat api pada perkebunan kelapa sawit.

\section{Bahan Dan Metode}

Penelitian ini dilakukan di Laboratorium Kimia Organik dan Laboratorium Teknologi Bioproses Politeknik Teknologi Kimia Industri (PTKI) Medan, Laboratorium Bioteknologi LIPI Cibinong, Bogor dan PTPN IV Marihat Unit Balimbingan, Siantar.

Peralatan yang digunakan pada penelitian ini adalah pisau (cutter), toples, kain kasa, blender, gunting, saringan, botol semprot, neraca analitik, pipet mikro, pinset, spatula, kertas saring Whatman, alumunium foil, rotary evaporator, FTIR dan peralatan gelas. Bahan yang digunakan adalah daun sirsak, akuades, etanol 96\%, ulat api (Setothosea asigna V.Eecke) dan daun kelapa sawit. 


\section{Preparasi Sampel}

Daun sirsak segar sekitar $5 \mathrm{~kg}$ dikering anginkan selama 10 hari, dan selanjutnya di haluskan hingga menjadi bubuk dengan menggunakan blender.

\section{Ekstraksi Daun Sirsak}

Bubuk daun sirsak dimaserasi dengan pelarut etanol 96\%. Hasil maserasi disaring dengan kertas saring. Pelarut dari ekstrak tersebut dipisahkan dengan rotary evaporator. Hasil pemisahan dipekatkan lagi dengan menggunakan hotplate stirer sehingga diperoleh crude ekstrak (ekstrak pekat). Crude ekstrak yang berwarna pekat disimpan dalam suhu kamar $\left( \pm 25^{\circ} \mathrm{C}\right)$ untuk menjaga agar senyawa pada crude ekstrak tidak rusak (Madhumathy et al., 2007)

\section{Pembuatan Larutan}

Ekstrak pekat yang telah didapatkan dari hasil Rotary evaporator diencerkan dengan aquades menjadi beberapa variasi konsentrasi yaitu 10\%, $20 \%, 30 \%, 40 \%$ dan $50 \%$. Pembuatan larutan menggunakan labu ukur 25 ml dan pipet mikro untuk mengambil crude ekstrak.

\section{Identifikasi Gugus Fungsi Crude Ekstrak}

Crude ekstrak daun sirsak diambil sebanyak $2 \mathrm{~mL}$ dan diteteskan pada alat Fourier Transform Infra Red Spectroscopy (FTIR) untuk melacak gugus fungsi dari acetogenin melalui komputer yang menggunakan perangkat lunak OPUS yang berbentuk grafik.

\section{Uji Insektisida}

Hama ulat api sebanyak 90 larva dibagi menjadi 6 kelompok. Daun muda kelapa sawit dimasukkan ke dalam wadah, hama ulat api diambil dengan menggunakan pinset, selanjutnya ulat api disemprot dengan variasi konsentrasi sesuai kelompok variasi. Kelompok S0 sebagai pembanding (insektisida kimia) disemprot dengan insektisida Deltamethrin, kelompok S1 disemprotkan dengan ekstrak daun sirsak $10 \%$, kelompok S2 disemprot dengan ekstrak daun sirsak $20 \%$, kelompok S3 disemprotkan dengan ekstrak daun sirsak 30
\%, kelompok S4 disemprot dengan ekstrak daun sirsak $40 \%$, kelompok S5 disemprot dengan ekstrak daun sirsak $50 \%$. Ulat api (instar 2 - instar 5) dimasukkan ke dalam wadah sejumlah 5 ekor kemudian diamati selama beberapa jam. Uji insektisida ini dilakukan sebanyak 3 kali pengulangan.

\section{Hasil dan Pembahasan}

Dari proses maserasi didapatkan filtrat sebanyak 9 L. Maserasi adalah teknik yang digunakan dalam pembuatan anggur yang kemudian diadaptasikan di dalam penelitian tanaman obat. Maserasi melibatkan perendaman tanaman dan dibiarkan pada suhu kamar selama minimal 3 hari disertasi agitasi ataupun tidak. Proses ini bertujuan untuk memecahkan dinding sel tanaman untuk melepaskan fitokimia yang terlarut (Azwanida, 2015). Dari hasil maserasi diperoleh crude ekstrak yang berwarna hijau pekat kehitaman seperti terlihat pada gambar 1 .

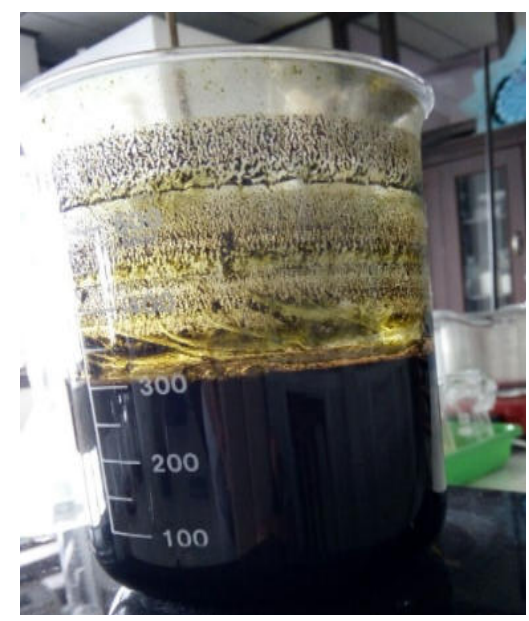

Gambar 1. Crude ekstrak daun sirsak

Hasil Fourier Transform Infra Red Spectroscopy (FTIR)

Analisis FTIR dilakukan untuk memprediksi gugus fungsi dari senyawa yang terdapat dalam crude ekstrak. Hasil FTIR diperlihatkan pada gambar 2 . 


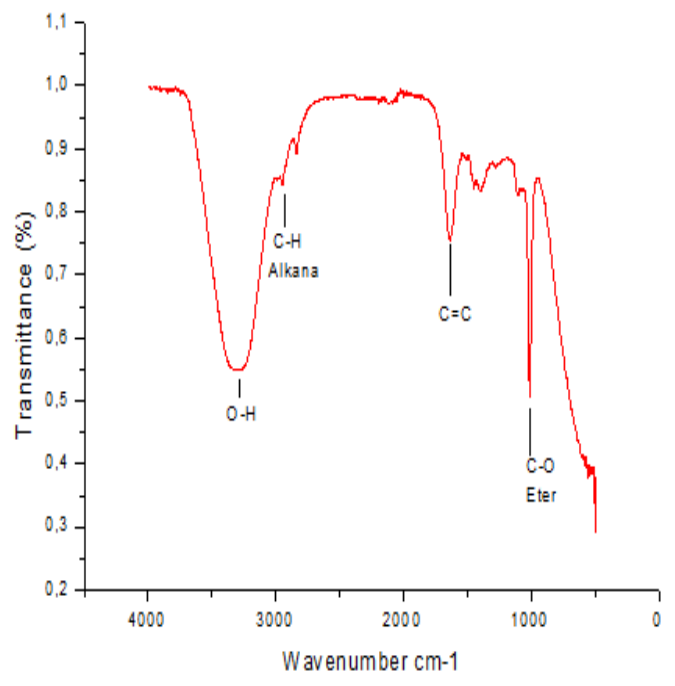

Gambar 2. Hasil Fourier Transform Infra Red Spectroscopy crude ekstrak daun sirsak

Dari hasil FTIR diatas, didapatkan pada daerah 1000-1300 $\mathrm{cm}^{-1}$ merupakan puncak spektrum gugus C-O (eter). Pada daerah 1620$1680 \mathrm{~cm}^{-1}$ menunjukkan spektrum gugus $\mathrm{C}=\mathrm{C}$ (alkena). Pada 2850-3000 $\mathrm{cm}^{-1}$ menunjukkan spektrum C-H (alkana). Daerah 3200 - 3600 $\mathrm{cm}^{-1}$ merupakan daerah spektrum untuk gugus $\mathrm{O}-\mathrm{H}$ (alkohol). Dalam penelitian lain dilaporkan bahwa gugus fungsi daun sirsak dalam bentuk cairan dan padat dianalisa memiliki spektrum puncak lebar pada $3262,75 \mathrm{~cm}^{-1}$ adalah gugus fungsi $\mathrm{OH}$, sementara pada fase cairan gugus $\mathrm{OH}$ ditunjukkan pada panjang gelombang 3327,21; gugus $\mathrm{CH}_{2}$ dan alkuna pada 2936,15 $\mathrm{cm}^{-1}$, pada $1394,17 \mathrm{~cm}^{-1}$ terdapat gugus $\mathrm{CH}_{3}$, gugus ester COC pada $1261 \mathrm{~cm}^{-1}$. Spektrum IR menunjukkan adanya gugus hidroksi dengan puncak yang tajam dan luas pada $3262,75 \mathrm{~cm}^{-1}$. Berdasarkan struktur annonaceous acetogenins dari sirsak, adanya alkane, alkuna, ester, cincin aromatic dan gugus hidroksil dapat di deteksi melalui analisis FTIR (Daud et al., 2016)

\section{Uji Insektisida}

Hasil uji insektisida ekstrak daun sirsak ditampilkan dalam tabel 1.
Tabel.1 Waktu kematian ulat api dengan perlakuan deltamethrin dan ekstrak daun sirsak

\begin{tabular}{cc}
\hline Perlakuan & Rataan (detik) \\
\hline S0 & $3534 \mathrm{~b}$ \\
S1 & $18033 \mathrm{a}$ \\
S2 & $17535 \mathrm{a}$ \\
S3 & $17378 \mathrm{ab}$ \\
S4 & $16729 \mathrm{ab}$ \\
S5 & $12867 \mathrm{ab}$ \\
\hline Keterangan : Nilai yang diikuti oleh huruf yang \\
\multicolumn{2}{c}{ sama menunjukkan tidak } \\
\multicolumn{2}{c}{ berbeda nyata pada uji lanjut } \\
Tukey 5\%
\end{tabular}

Dari tabel di atas dapat dilihat bahwa waktu kematian kelompok S0 (deltamethrin) tidak berbeda nyata dengan perlakuan S3, S4 dan S5 tetapi berbeda nyata dengan S1 dan S2. Dari hasil ini dapat disimpulkan bahwa semakin tinggi konsentrasi ekstrak daun sirsak maka semakin cepat waktu yang dibutuhkan untuk membunuh hama ulat api. Ciri fisik ulat api setelah perlakuan adalah ulat mati dengan badan ulat menjadi kaku, perut menggelembung, kulit mengkerut dan beberapa ulat tubuhnya menyusut dan mengeluarkan cairan seperti terlihat pada Gambar 3.

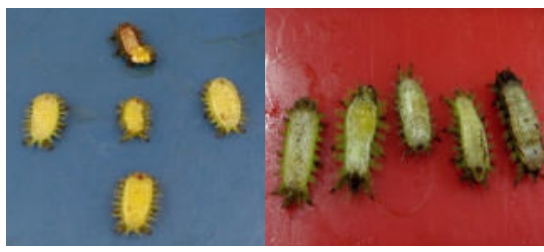

(a)

(b)

Gambar 3 : (a) perlakuan ulat api dengan deltamethrin, (b) perlakuan ulat api dengan ekstrak daun sirsak $30 \%$

Dalam penelitian lain dilaporkan mengenai potensi ekstrak sirsak sebagai bioinsektisida terhadap Callosobruchus maculatus. Konsentrasi ekstrak yang digunakan adalah 0 g, 1 g, 0,5 g, 2 g da 3 g. Setiap variasi konsentrasi ditambahkan ke bejana yang mengandung 20 biji lalu diaduk dan ke dalam bejana tersebut dimasukkan larva sebanyak 10 ekor. Hasil penelitian 
menunjukkan ekstrak bubuk daun sirsak memiliki rata-rata mortalitas yang tertinggi dengan nilai 59,9, diikuti dengan bubuk biji $(89,8)$, kulit pohon $(89,4)$ dan bubuk akar $(88,3)$ (Ishuwa et al., 2016). Dalam penelitian lain dilaporkan bahwa ekstrak biji sirsak berpotensi sebagai sebagai insektisida pada $S$. Zeamais. Biji Sirsak di ekstrak dengan menggunakan pelarut heksana (non polar), etil asetat (semi polar) dan etanol (polar). Nilai $\mathrm{LC}_{50}$ ditentukan dengan bioassay ingestion (ditelan). Nilai $\mathrm{LC}_{50}$ ekstrak non polar adalah 4009; 3854; dan 3760 ppm pada waktu 24, 48 dan 72 jam. Untuk ekstrak etil asetat adalah 3280; 2667 dan 2542 ppm pada waktu yang sama. Untuk bioassay secara topikal, nilai $\mathrm{LC}_{50}$ ekstrak heksana adalah 9368 ppm pada 72 jam. Semua larva mati pada konsentrasi etil asetat dan heksana 2500 ppm dan 5000 ppm untuk ekstrak etanol. Efektifitas ekstrak etanol lebih rendah daripada ekstrak non polar dan semipolar. Efek insektisida ini kemungkinan disebabkan oleh adanya acetogenin yang merupakan fraksi yang kurang polar. Acetogenin mempunyai banyak sekali aktivitas biologi, seperti imunosupresif, anti malaria, insektisida dan antifeedant. Senyawa ini banyak ditemukan di daun, ranting dan biji tanaman annonaceous. Mekanisme acetogenin sebagai insektisida adalah dengan menghambat NADH ubikuinon reduktase (complex I) rantai pernapasan, dan secara langsung mempengaruhi transpor elektron di mitokondria menyebabkan penurunan kadar ATP sehingga sel mengalami apoptosis (Kojima \& Tanaka, 2009).

\section{Kesimpulan}

Dari penelitian yang telah dilakukan, maka dapat disimpulkan bahwa daun sirsak dapat dimanfaatkan sebagai biopestisida dalam mengendalikan hama ulat api dengan mekanisme racun kontak dan konsentrasi ekstrak daun sirsak 30\% sudah efektif dalam mengendalikan hama ulat api pada perkebunan kelapa sawit.

\section{Daftar Pustaka}

Azwanida, N. N. 2015. Medicinal \& Aromatic
Plants A Review on the Extraction Methods Use in Medicinal Plants, Principle , Strength and Limitation. Med. Aromat. Plants, $\quad 4:$ 2-6. https://doi.org/10.4172/2167-

0412.1000196

Damalas, C. A., \& Eleftherohorinos, I. G. 2011. Pesticide Exposure, Safety Issues, and Risk Assessment Indicators. Int. J. Environ. Res. Publich Heal., 8: 1402-1419. https://doi.org/10.3390/ijerph8051402

Daud, N. N. N. N. M., Ya'akob, H., \& Rosdi, M. N. M. 2016. Integrative Cancer Science and Therapeutics Acetogenins of Annona muricata leaves: Characterization and potential anticancer study. Integr. Cancer Sci. Ther., 3 (4): 543-551. https://doi.org/10.15761/ICST.1000202

Ishuwa, M. N., Elkanah, O. S., \& Wahedi, J. A. 2016. Grain Protectant Potential of Annona muricata and A . senegalensis against Cowpea Seed Bruchid Callosobruchus maculatus Fab . ( Coleoptera: Bruchidae ). Asian Res. J. Agric., 1: 1-7. https://doi.org/10.9734/ARJA/2016/265 05

Khater, H. F., \& Khater, D. . 2009. Tropical medicine rounds The insecticidal activity of four medicinal plants against the blowfly Lucilia sericata ( Diptera: Calliphoridae ). Trop. Med. Rounds, 48: 492-497.

Kojima, N., \& Tanaka, T. 2009. Medicinal Chemistry of Annonaceous Acetogenins: Design, Synthesis, and Biological Evaluation of Novel Analogues. Molecules, 14: 3621-3661. https://doi.org/10.3390/molecules14093 621

Madhumathy, A., Aivazi, A.-A., \& Vijayan, V. 2007. Larvicidal efficacy of Capsicum annum against Anopheles stephensi and Culex quinquefasciatus. J Vect Borne Dis, 44: 223-226.

Ndakidemi, B., Mtei, K., \& Ndakidemi, P. A. 2016. Impacts of Synthetic and Botanical Pesticides on Beneficial Insects. Agric. Sci., 7: 364-372. 
Pai, B. H. M., Rajesh, G., Shenoy, R., \& Rao, A. 2016. Anti-microbial Efficacy of Soursop Leaf Extract ( Annona muricata ) on Oral Pathogens: An In-vitro Study. J. Clin. Diagnostic Res., 10: 1-4. https://doi.org/10.7860/JCDR/2016/183 29.8762

Saleh, A., \& Siregar, A. Z. 2017. Impact of Natural Enemies To Leaf Eating Caterpillar Population On Oil Palm In North Sumatra, Indonesia. Int. J. Sci. Technol. Res., 6: 20152018.

Sharma, K. R., \& Thakur, S. 2018. BIOPESTICIDES : AN EFFECTIVE TOOL FOR INSECT PEST MANAGEMENT AND Indian Journal of Agriculture. Indian J. Agric. Allied Sci., 4: 59-62.

Sinaga M, Oemry S, L. 2015. Efektivitas Beberapa Teknik Pengendalian Setothosea asigna pada Fase Vegetatif Kelapa Sawit di Rumah Kaca. J. Online Agroekoteknologi, 3: 634-641.

Trindade, R. C. P., Luna, J. D. S., De Lima, M. R. F., Da Silva, P. P., \& Sant'ana, A. E. G. 2016. Larvicidal activity and seasonal variation of Annona muricata (Annonaceae ) extract on Plutella xylostella ( Lepidoptera: Plutellidae ) Larvicidal activity and seasonal variation of Annona muricata ( Annonaceae ) extract on Plutella xylostella ( Lepidop. Rev. Colomb. Entomol., 37: 223227. 